\title{
MARIA, LUANNA E MUITAS HISTÓRIAS...
}

\section{DEISE AZEVEDO LONGARAY ${ }^{1}$}

Olá, pessoal... Tudo bem? Que bom estar aqui novamente contando para vocês o que tem acontecido na minha vida, na minha escola e com meus/minhas amigos/as. Tenho muitas coisas para contar, mas, hoje, vou falar outra vez sobre a Luanna. Lembram dela? É. Essa mesmo. A que nasceu Thiago e agora é reconhecida por Luanna. Lembram que contei que o professor Daniel discutiu muitas coisas conosco a partir da história dela? Falamos sobre nome social e sobre o banheiro unissex na escola. Então, tenho novidades, algumas coisas tristes para contar, mas também muita coisa legal. A equipe pedagógica e diretiva da nossa escola estava discutindo sobre a possibilidade de construir banheiros unissex, lembram? E adivinhem? Conseguimos... Vivaaa!!! A Luanna já não passaria mais por aqueles constrangimentos e situações desagradáveis que ela sofria. É passaria, sim! Porque, infelizmente, a Luanna não está mais na minha escola. Continuamos amigas, até mais do que antes. Mantemos contato direto pelo whatsapp e de vez em quando nos encontramos. Mas agora, há outra coisa que está preocupando Luanna e também a nós, amigas dela.

A Luanna mudou de escola porque seus pais se separaram e a mãe dela, com quem ela mora, mudou de casa. Foi morar com a avó dela, que mora muito longe da nossa escola. Assim, Luanna também teve que trocar de escola e lá tem enfrentado algumas coisas chatas, mas também muita coisa legal vem sendo feita por lá, no sentido de combater o preconceito. Mas sobre isso vou contar depois, na verdade tenho uma surpresa pra vocês. Mas só vão saber daqui a pouco, porque agora vou contar porque os pais da Luanna se separaram.

O pai da Luanna está com um probleminha de saúde. Na verdade, ele está é com um problemão. Ou melhor, a Luanna e a mãe dela é que estão. Seu Valdir, pai da Luanna, é alcoolista bebia e brigava muito com a filha e com dona Tânia, mãe da Luanna. Daí, um dia, dona Tânia e seu Valdir estavam discutindo quando ele disse que seu filho tinha se

\footnotetext{
${ }^{1}$ Doutora e Mestre em Educação em Ciências, Licenciada em Ciência Biológicas e Integrante do Grupo de Pesquisa Sexualidade e Escola - GESE.
}

Rev. Diversidade e Educação, v. 5, n. 1, p. 51-56, jan./jun. 2017. 
transformado numa "mulherzinha" por culpa dela. Ele disse que a Luanna era doente porque a mãe permitia que ela fizesse tudo que queria, sem colocar limites. Ela ficou arrasada quando escutou seu pai, que ela tanto ama, dizendo isso, que ela era doente e que sua mãe era a culpada. Doente? Luanna não é doente. É?

Pessoal, tudo isso Luanna me contou pelo whatsaap. Fiquei muito triste, porque ela também estava aborrecida e eu não podia nem abraçar ela naquele momento. Fiquei muito chateada, porque com a mudança de endereço e de escola ficamos longe uma da outra. Moramos bem distantes agora, mas nada impede nossa amizade. Tenho a impressão que ficamos mais próximas, porque agora ela se abre mais comigo, mesmo que seja por mensagens e telefonemas. Então, deixa eu continuar contando...

A Luanna, com essa história do pai dizer que ela era doente, ficou muito encucada. Procurou muitas histórias na internet e matérias sobre pessoas transexuais e transgêneras para saber um pouco mais sobre a transexualidade e essa coisa de ser doença ou não. Foi aí que ela conheceu a história da pesquisadora Letícia Lanz, do João Nery e de outras pessoas que se reconhecem como transexuais e como pessoas transgêneras. Inclusive, nesta edição da Revista Diversidade e Educação vamos ter textos e discussões sobre a temática transexualidade, pessoas transgêneras entre outros assuntos. Vai ser bem legal!

Continuando a história... $\mathrm{Na}$ escola que a Luanna está agora tem umas profs que estão fazendo uma atividade bem legal. Elas estão desenvolvendo um trabalho sobre Igualdade de Gênero. A Luanna disse que a professora dela está participando de um curso na Universidade Federal do Rio Grande (FURG). Já comentei com vocês que lá tem um pessoal que desenvolve vários trabalhos sobre sexualidade, gêneros e etc. O GESE, lembram? Então, esse grupo está promovendo um curso para professores e professoras que se chama "Escolas Promotoras da Igualdade de Gênero" e a professora da Luanna está participando desse projeto desenvolvendo um trabalho bem legal sobre igualdade de gênero na turma dela. A Luanna está super empolgada porque está discutindo e aprendendo um monte de coisas legais sobre gênero, sexualidade e preconceito.

Foi em um desses encontros do projeto que a professora está desenvolvendo que a Luanna perguntou sobre essa coisa dela ser doente. Mas essa parte quem vai contar não sou eu. É a própria Luanna. Isso mesmo. Eu não disse que tinha uma surpresa pra vocês leitores/as? Então, essa é a surpresa. Ela que vai explicar tudo direitinho, contar sobre as coisas que vêm acontecendo com ela. Então, essa é a Luanna!!!

Rev. Diversidade e Educação, v. 5, n. 1, p. 51-56, jan./jun. 2017. 
Olá, pessoal. Tudo bem? Como a Maria já disse, eu sou a Luanna, com dois Ns, tá. Adoroooo! Depois que deixei de ser o Thiago com H, adorei ser a Luanna com dois Ns. Brincadeiras à parte, vim aqui a convite da Maria para contar um pouco do que está se passando comigo. Minha professora, a Claudia, está fazendo um curso lá na FURG e vem realizando um trabalho sobre gênero conosco, muito legal. Mas, vocês não vão acreditar o que um colega meu, o Pietro, falou.

A professora estava debatendo com a gente sobre as atividades ditas masculinas e femininas, sobre os atributos e as funções que são associadas às mulheres e tal. Falamos sobre as desigualdades que existem em muitos aspectos entre homens e mulheres, como a questão de oportunidades de emprego, de diferença nos salários, das violências que as mulheres sofrem nos diferentes espaços que circulam e convivem. Daí, eu comentei que na minha casa, quando morava com meu pai, ele não queria lavar a louça porque dizia que era coisa de mulher. E eu dizia que nada a ver, que lavar a louça não era uma coisa tão legal de fazer, mas que é atividade de homem e de mulher, mas ele insistia nessa ideia. Que homem não fazia essas coisas. Aí, o meu colega fala assim:

- Luanna, se não é tão legal assim lavar louças e fazer coisas ditas de mulher, se existe tanta desigualdade e violência contra as mulheres, porque tu escolheste ser mulher?

Aí, meu queixo caiu, né, pessoal. Fiquei chocada com essa pergunta. Respirei fundo, olhei pra professora, ela me olhou com uma cara de quem diz: pode responder. Daí, eu tive que falar. Falei que o que acontece comigo não vem de uma escolha. Que escolher, eu escolho a roupa que visto, o perfumo que uso, o sapato que quero colocar, isso sim são escolhas, mas o meu jeito de ser, não é uma escolha. Eu sempre me senti assim. Nunca me encaixei nas coisas que as pessoas dizem que é de menino. Quando eu era pequena e minha mãe me levava pra brincar com meus primos e primas, eu não queria fazer as coisas que os guris faziam, pois não me chamava atenção. Eu gostava de brincar de coisas que as minhas primas gostavam, quer dizer, colocar os vestidos e as sandálias delas e usar maquiagem. Sempre foi assim.

Falei para o Pietro que eu não escolhi ser assim, eu simplesmente sou. Será que isso é tão difícil de entender? Por que as pessoas têm tanto preconceito com isso? Eu sofro preconceito diariamente com relação a isso, tu achas que eu escolheria passar por essa situação todos dos dias? Perguntei pra ele. Ele disse que não entendia muito isso que acontecia comigo, mas que eu deveria pensar muito bem, porque não ia ser tão fácil a minha vida. Ele disse que viu uma reportagem que as pessoas transexuais sofrem muito. Rev. Diversidade e Educação, v. 5, n. 1, p. 51-56, jan./jun. 2017. 
Dizem que isso é ser transexual. Mas eu não sei se sou transexual. Sei que não me vejo e não me entendo como um menino. Isso é ser transexual? Acho que vou entender um pouco mais dessas coisas depois que ler os textos dos pesquisadores João Nery e Letícia Lanz, parece que eles vão falar sobre isso aqui na revista.

A professora aproveitou esse momento e resolveu falar umas coisas para a nossa turma. Ela disse que a medicina considera a transexualidade uma disforia de gênero e que isso, de ser associado à doença, é usado como argumento para as pessoas fazerem a mudança de sexo pelo SUS, por exemplo. Mas que ela não considerava as pessoas transexuais doentes e nem poderia dizer se eu era transexual, porque isso é uma questão de identificação, de se reconhecer como tal. Só eu, talvez com o tempo, saiba dizer se sou ou não trans. Adorei o que a professora Claudia falou, porque é bem isso mesmo. Eu sei o que sinto e como me sinto, mas não sei dizer se sou transexual. E essa coisa de mudança de sexo é complicada, eu não sei se um dia vou querer fazer essa cirurgia. Por enquanto nem penso nisso. Para vocês isso é difícil de entender, pessoal? E ainda bem que a professora falou isso de eu não ser doente, porque já estava preocupada. Porque vocês não sabem, né, mas a minha avó, com quem estou morando agora, acha que minha mãe tem que me levar no psicólogo, psiquiatra, essas coisas. Pra ver o que tem na minha cabeça. Minha avó fica dizendo que não está certo, porque sou o único neto dela. Ela fica dizendo como vou dar esse desgosto para ela de querer deixar de ser o único neto e ser mulher? Aí, eu nem explico mais, tadinha ela não vai entender.

A professora Claudia disse que lá na FURG, onde ela está fazendo esse curso sobre igualdade de gênero, tem um grupo que conversa sobre várias coisas com relação às identidades de gênero. Ele é coordenado pela professora Paula Ribeiro e nesse grupo os/as participantes falam sobre muitas coisas como: nome social, hormônios, mudanças no corpo, sobre a família, sobre muitas coisas que se passa na vida de alguns e algumas transexuais que participam do grupo. Eu disse pra prof. que quero conhecer esse grupo até para entender mais o que acontece comigo e até queria levar minha mãe junto, porque ela me respeita, sabe? Mas é muito difícil, às vezes, ela ouvir umas coisas que falam sobre mim nos diferentes lugares como: na escola, nas lojas e até mesmo dentro de casa. Essas coisas que minha avó, tadinha, fala. E o que meu pai também falou. Para ela é muito ruim ouvir isso, porque ela também não sabe o porquê de eu ser assim, mas ela simplesmente me deixa ser EU. Então, um dia eu quero ver se conheço esse grupo, o nome dele é Transformando Vidas! Achei o máximo!!!

Rev. Diversidade e Educação, v. 5, n. 1, p. 51-56, jan./jun. 2017. 
É muito bom ouvir as coisas que professora Claudia está trazendo para nossas aulas. Ela disse que vamos debater bastante sobre várias questões associadas aos gêneros.

Então, pessoal, só para finalizar esse papo, queria dizer que foi muito bom, Maria, você me convidar para vir aqui contar um pouco do que vem se passando na minha vida. Gostei muito do que a professora Claudia falou em aula sobre essa coisa de igualdade de gênero. Ela disse para o Pietro que acima de tudo as pessoas devem respeitar os/as outros/as, suas diferenças. Que não interessa se eu nasci menino e agora me sinto como uma menina, que se eu quero ser reconhecida e entendida dessa forma, o que interessa e importa é que as pessoas precisam respeitar umas as outras e não as julgar. Ela finalizou a conversa, desse dia, com uma frase muito legal. Somos todos humanos, independente de raça, cor, religião, orientação sexual e identidade de gênero. E que o meu jeito de ser é só mais um entre outros tantos que existem. Por isso, que eu cheguei a conclusão que eu não sou doente nada, nem anormal, eu sou gente e quero ser respeitada como sou. É só mais um modo de ser e viver! É só isso que as pessoas precisam entender.

Por isso, Maria, te agradeço muito por me convidar para estar aqui, pois sei que tu me entendes e me respeitas. Estou louca para ver quais serão as próximas discussões que a professora Claudia vai fazer nesse projeto. Foi triste ter mudado de escola porque me afastei das minhas amigas, mas teve o lado bom, porque eu conheci a professora Claudia que está falando coisas bem interessantes que me deixam feliz. Porque mesmo que exista preconceito tem muita gente querendo acabar com ele, como, por exemplo, as professoras que estão fazendo o mesmo projeto da professora Cláudia. Elas estão lá para discutir sobre a igualdade de gênero, fazendo com que a sociedade seja menos preconceituosa e menos violenta. Obrigada, Maria, por me deixar vir aqui contar essas coisas.

Pois é, pessoal, gostaram de acompanhar um pouco da história da Luanna, contada por ela mesma? Eu achei bem bacana. Convidei-a para vir porque ela também faz parte da minha vida, ela também está entre as histórias de Maria. Obrigada Luanna, obrigada leitores/as e até a próxima.

Rev. Diversidade e Educação, v. 5, n. 1, p. 51-56, jan./jun. 2017. 


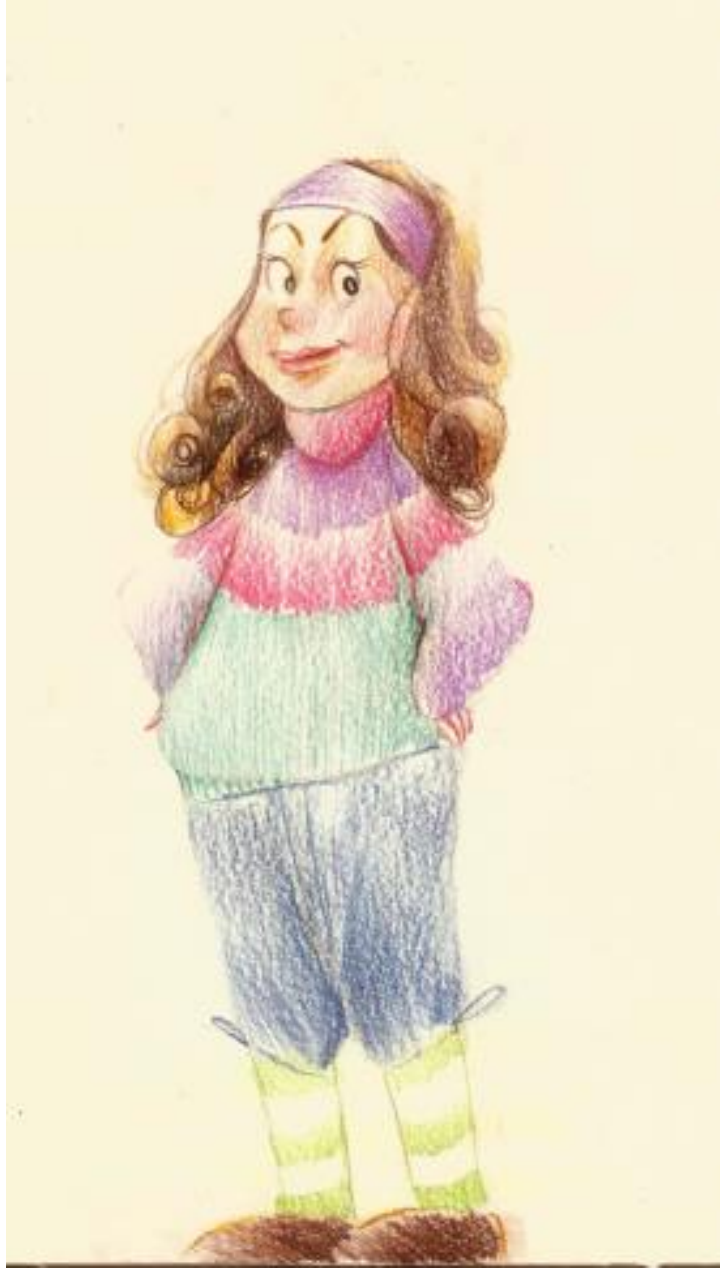

Maria

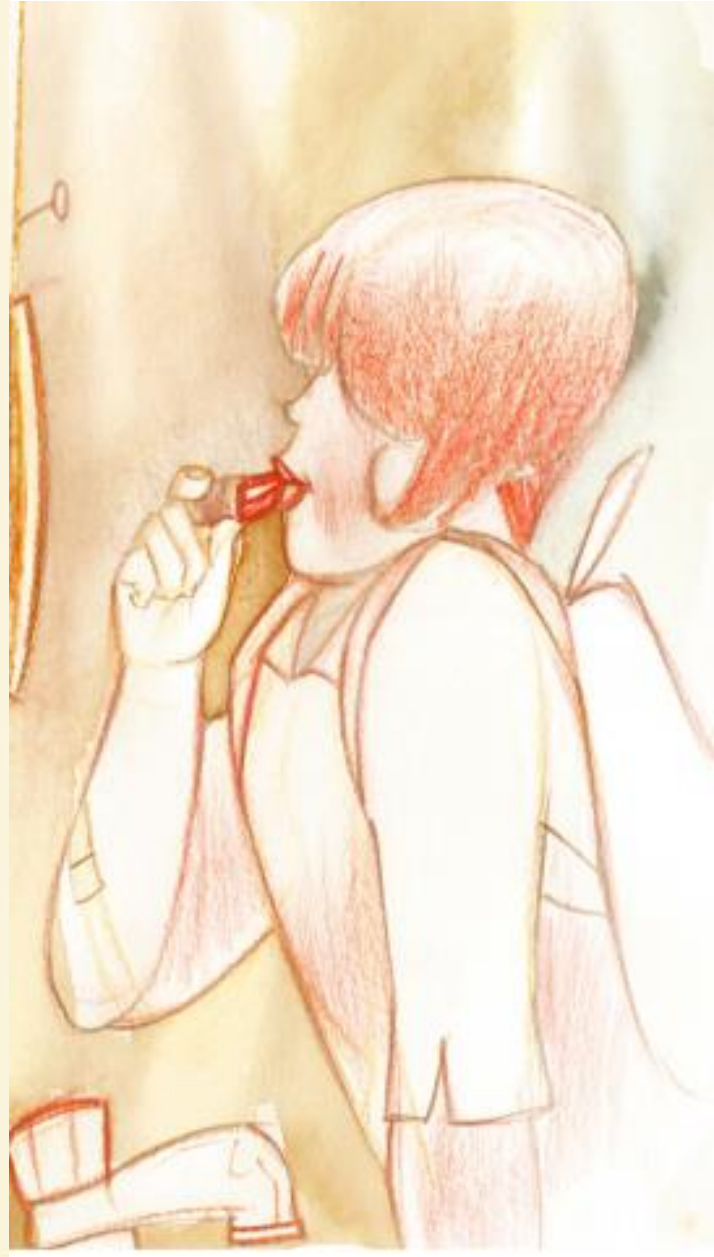

Luanna

Rev. Diversidade e Educação, v. 5, n. 1, p. 51-56, jan./jun. 2017. 